NBER WORKING PAPER SERIES

\title{
SOCIAL SECURITY AND TRUST FUND MANAGEMENT
}

\author{
Takashi Oshio \\ Working Paper 10444 \\ http://www.nber.org/papers/w10444
NATIONAL BUREAU OF ECONOMIC RESEARCH
1050 Massachusetts Avenue
Cambridge, MA 02138
April 2004

The original draft of this paper was presented to the sixteenth annual NBER-CEPR-TCER conference, which was held in Tokyo, Japan, in December 8 and 9, 2003. I thank Yasushi Iwamoto and Charles Y. Horioka, who were the discussants for my paper, as well as other participants at the conference for helpful comments. I also acknowledge financial support from the grants: "the Scientific Researches of Priority Areas 603: Project on Intergenerational Equity" from the Ministry of Education, Science and Culture, Japan. The views expressed herein are those of the author(s) and not necessarily those of the National Bureau of Economic Research.

(C2004 by Takashi Oshio. All rights reserved. Short sections of text, not to exceed two paragraphs, may be quoted without explicit permission provided that full credit, including $\mathbb{C}$ notice, is given to the source. 
Social Security and Trust Fund Management

Takashi Oshio

NBER Working Paper No. 10444

April 2004

JEL No. H55, H23

$\underline{\text { ABSTRACT }}$

In this paper we investigate why and to what extent the government should have a social security trust fund, and how it should manage the fund in the face of demographic shocks, based on a simple overlapping-generations model. We show that, given an aging population, a trust fund in some form could achieve the (modified) golden rule or to offset the negative income effect of a PAYGO system. Besides, in a closed economy where factor-prices effects dominate, using the trust fund as a buffer for demographic shocks could lead to a widening of intergenerational inequality. We also the discuss policy implications of our analysis on the social security reform debate in Japan, including the fixed tax method and the use of the trust fund in the face of a rapidly aging population.

Takashi Oshio

Kobe University

2-1 Rokkodai-cho, Nada-ku

Kobe, Hyogo, 657-8501

oshio@econ.kobe-u.ac.jp 


\section{Introduction}

The Japanese government has a huge social security trust fund, which amounted to nearly 150 trillion yen for the Employees' Pension Insurance program (EPI; Kosei Nenkin Hoken) at the end of 2002. This is equivalent to about five years of EPI benefits, compared to about three years of benefits in the United States and only one to two months of benefits in the United Kingdom, Germany, and France. In a pure pay-as-you-go (PAYGO) system, the social security taxes paid by young workers and benefits paid to retirees are balanced at any time. In reality, however, tax revenue can both exceed and fall below benefit payments, and the gap between the two determines the path of the trust fund.

The very high level of the Japanese trust fund implies that social security taxes have generally exceeded benefit payments. This presumably reflects Japan's relatively young population structure thus far, as well as the government's strategy of building up the trust fund before facing a rapidly aging population. Given pessimistic prospects for birthrates and wage income growth, however, the current level of the trust fund appears not to be sustainable. In fact, the trust fund has started to fall short of official projections in recent years, mostly due to a reduction in social security tax revenue, reflecting lackluster economic conditions.

It is unclear, however, what the optimal level of the trust fund is and how the government should manage it. European governments do not require a huge trust fund as they use the fund simply to absorb unexpected, temporary shocks to social security finances. Alternatively, the government seems to be able to use the trust fund more strategically. For instance, it is often argued that the government should redistribute income between generations through the fund to hold down social security taxes on smaller cohorts. Also, as suggested by Feldstein (1974)'s argument, the government may want to accelerate 
capital accumulation by increasing payroll taxes and adding them to the trust fund.

In fact, how to manage the trust fund in the long run is one of main issues in the social security reform debate in Japan. The Ministry of Health, Labor, and Welfare (MHLW), which is in charge of Japanese social security programs, has repeatedly claimed that it should keep the trust fund at a high level to hold down future increases in social security taxes given a rapidly aging population. This affects the current generations because, to sustain the trust fund at a certain level, they have to give up an opportunity to pay lower taxes or receive higher benefits. Indeed, the MHLW plans to continue raising the tax rate over the next decades, albeit with the trust fund at hand at a high level. More and more politicians and economists now insist that the government should start to reduce the trust fund to mitigate demographic pressures, which are expected to mount rapidly in the future.

The outlook for the trust fund is also one of the key issues in the social security debate in the United States. The U.S. Social Security Trust Fund now amounts to over one trillion dollars, but the latest 2003 Social Security Trustee's Report released the official projection that the OASDI trust fund will be exhausted sometime around 2042. In the United States the baby boom generation will begin to retire around the year 2010 , at which time the large trust fund will start to be run down. If the fund is exhausted, benefits would have to be cut and/or taxes raised, or the government would have to completely change the social security programs. Aaron and Reischeuer (1998) insist on shifting the existing trust fund from (non-marketable) government bonds to private securities to raise the rate of return of the trust fund, thereby extending the period before its balance is exhausted. Federal Reserve chairman Greenspan (1999) and many others criticize this, however, arguing that such a shift in the portfolio of the fund would do nothing for national savings and social welfare.

This paper investigates why and to what extent the government needs the trust fund in social security policies, and how it should manage the fund in the face of demographic 
shocks, based on a simple overlapping-generations model ${ }^{1}$. As pointed out by Burbidge (1983), Myles (1995), Abel (2001) (2003) and others, the trust fund, if appropriately managed, can help a PAYGO system to enhance capital stock and social welfare in the long run. Following these studies, we first discuss what factors can affect the optimal level of the trust fund, showing that it is difficult to manage a PAYGO system without the trust fund given an aging population. We demonstrate that social security can potentially affect national savings and capital accumulation, especially if it has a trust fund, within the general equilibrium framework of overlapping-generations models. We also discuss how these results change, if we assume a small open economy in which the impact on capital accumulation is neglected.

Second, we examine how social security policy should tackle demographic shocks. A PAYGO system is often criticized for making a small cohort worse off, and using the trust fund is considered to be a "buffer", which is expected to absorb the adverse impact of a declining population. This seems to make sense, if we ignore the impact on capital accumulation and on factor prices; in other words, if we live in a small open economy. In a closed economy, however, a small cohort can enjoy positive factor-price effects due to a higher capital-labor ratio, while a large cohort will have to face a lower level of lifetime income and utility. Indeed, Smith (1982) shows that a PAYGO system can raise social welfare by enabling intergenerational transfers of income. Also, Bohn (2001) emphasizes that even within the framework of defined benefits a small cohort may be better off due to factor-price effects. Thus, from an inter-temporal insurance perspective, it is debatable whether the government should use the trust fund to absorb demographic shocks. Moreover, if the government uses the fund to hold down the tax burden on a certain

${ }^{1}$ We do not discuss political and institutional issues-such as political independence of the trust, problems associated with the government as a shareholder-and of the administrative cost aspects of managing the trust fund (see Shoven (2002)). Detailed and comprehensive discussions on the economic worth of the trust fund are provided by Smetters (2003). 
generation, subsequent generations would receive lower interest on the trust fund. Thus, management of the trust fund over time is related to distribution issues.

The remainder of this paper is arranged as follows. Section 2 presents the theoretical framework on which our analysis is based and discusses the optimal structure of the social security system, which has both a PAYGO structure and the trust fund. Section 3 examines how the social security policy should respond to demographic shocks by comparing use of the trust fund and adjustment of the tax rate. Section 4 discusses the policy implications of these analyses on the management of the trust fund over the next decades in Japan. Finally, section 5 summarizes the main results and presents limitations of our analysis and future research topics.

\section{Theoretical framework}

\subsection{A simple model}

Our theoretical analysis is based on a very simple two-period life-cycle model, in which one works in period 1 and retires in period 2, explicitly taking into account a trust fund in social security policies. The idea of this model is basically the same as that presented by Burbidge (1983), Myles (1995), Abel (2001) (2003), and others. A representative individual born in period $t$ supplies one unit of labor in period $t$ and receives wage income, $w_{t}$. In period $t$, the individual pays a wage-proportional social security tax, $\theta_{t} w_{t}$ to the social security system at the tax rate, $\theta_{t}$. Upon retiring, the individual receives a lump-sum benefit, $b_{\mathrm{t}}$.

Then, the individual's lifetime budget constraint is given by

$$
c_{t}^{y}+\frac{c_{t+1}^{0}}{1+r_{t+1}}=\left(1-\theta_{t}\right) w_{t}+\frac{b_{t+1}}{1+r_{t+1}}
$$


where $c_{t}^{y}$ and $c_{t+1}^{o}$ denote consumption levels when young and old, respectively, and $r_{t+1}$ is the interest rate in period $t+1$. Bequests are neglected to assess the original impact on the individual's utility from policy changes. Subject to this budget constraint, the individual maximizes lifetime utility, which is given by

$$
u_{t}=u\left(c_{t}^{y}\right)+\frac{1}{1+\delta} u\left(c_{t+1}^{o}\right)
$$

where $u($.$) is instantaneous utility or felicity, and \delta$ is the individual's subjective rate of time preference. In this model, we concentrate on the impact of social security programs on lifetime income and consumption, ignoring other aspects of social security such as maintenance of the minimum level of retired income. If that is the case, it is widely known that a fully funded system is completely welfare-neutral. The first order condition for utility maximization is given by

$$
u^{\prime}\left(c_{t}^{y}\right)=\frac{1}{1+\delta} u^{\prime}\left(c_{t+1}^{o}\right)
$$

along with the budget constraint (1).

Next, we consider the social security program. In order to highlight the role of a social security trust fund, we assume that the government does not hold any other type of asset (or debt). We express a social security trust fund by $k_{t}^{s}$ per worker at the beginning of period $t$., and denote $L_{t}$ as the population size of generation $t$. In period $t$, the government receives interest on the trust fund, $L_{t} r_{t} k_{t}^{s}$, plus tax revenue $L_{t} \theta_{t} w_{t}$ from generation $t$. At the same time, the government pays pension benefits, $L_{t-1} b_{t}$ to generation $t-1$, which retires in period $t$. Then, the trust fund at the beginning of period $t+1$ is given by ${ }^{2}$

\footnotetext{
${ }^{2}$ Abel (2002) assumes that the government tries to prevent the trust fund from wandering too far from the target, which is given relative to the aggregated capital stock, and also to respond to the rate of return to the trust fund.
} 


$$
L_{t+1} k_{t+1}^{s}=\left(1+r_{t}\right) L_{t} k_{t}^{s}+L_{t} \theta_{t} w_{t}-L_{t-1} b_{t} .
$$

This relation suggests that if the government determines the tax rate and the benefit, the dynamics of the trust fund will be solved automatically. Assuming that the population size of generation $t$ is $\left(1+n_{\mathrm{t}}\right)$ times that of generation $t-1$, this accounting identity can be expressed in per capita terms as

$$
k_{t+1}^{s}=\frac{1}{1+n_{t+1}}\left[\left(1+r_{t}\right) k_{t}^{s}+\theta_{t} w_{t}-\frac{b_{t}}{1+n_{t}}\right]
$$

meaning that the stability of the dynamic path of the trust fund depends much on the relation between interest rate and population growth rate, because from (4),

$$
\frac{\partial k_{t+1}^{s}}{\partial k_{t}^{s}}=\frac{1+r_{t}}{1+n_{t+1}}>1 \text { for } r_{t}>n_{t+1} ;<1 \text { for } r_{t}<n_{t+1} .
$$

This suggests that as far as the trust fund is endogenously determined, its path tends to be unstable when the population growth rate is lower than the interest rate ${ }^{3}$. Given an aging population, it thus appears to be difficult for the government to use the trust fund as a buffer to demographic and other shocks, because the trust fund would amplify rather than absorb them, as discussed in more detail later. Alternatively, if the government establishes a strategy to accumulate the trust fund and sets the benefit (or the tax rate) at a certain level, the tax rate (or the benefit) will be adjusted to make this identity hold.

In this section, we concentrate on the trust fund and the tax rate, by eliminating $b$ from (1) using (5) and rewriting the individual's budget constraint as

$$
c_{t}^{y}+\frac{c_{t+1}^{0}}{1+r_{t+1}}=w_{t}+\left(\frac{n_{t}-r_{t+1}}{1+r_{t+1}}\right) \theta_{t} w_{t}+\frac{1+n_{t}}{1+r_{t+1}}\left[\left(1+r_{t}\right) k_{t}^{s}-\left(1+n_{t+1}\right) k_{t+1}^{s}\right]
$$

The second term on the right-hand side of this equation indicates the net return to a PAYGO

3 It should be noted that if the social security program is a pure PAYGO system, we know from (4) that the discount value of the aggregated trust fund is fixed over time. 
system, while the third term indicates net income obtained from the trust fund. In a pure PAYGO system, $k^{s}$ is always zero and the second term on the right-hand side of (7) disappears. In a fully funded system, taxes are always equal to the discounted value of the benefit, as well as the trust fund; that is, $\theta_{t} w_{t}=b_{t+1} /\left(1+r_{t+1}\right)=k_{t}^{s}$, thus both the second and third times of the right-hand side of (7) disappear, meaning the social security program is neutral to the individual's behavior and social welfare.

The equilibrium in the capital market means that the sum of household savings, which are given by $L_{t}\left[\left(1-\theta_{t}\right) w_{t}-c_{t}^{y}\right]$, and the trust fund $L_{t+1} k_{t+1}^{s}$ are equal to total capital, $L_{t+1} k_{t+1}$. Hence, we can express the dynamics of capital accumulation per worker as

$$
k_{t+1}=\frac{1}{1+n_{t+1}}\left[\left(1-\theta_{t}\right) w_{t}-c_{t}^{y}\right]+k_{t+1}^{s} .
$$

Finally, we assume as usual that factor prices are determined in competitive markets and that the rental price of each factor equals its marginal product; that is,

$$
r_{t}=f^{\prime}\left(k_{t}\right), w_{t}=f\left(k_{t}\right)-k_{t} f^{\prime}\left(k_{t}\right) \text {. }
$$

Equations (3), (7), (8), and (9) determine the endogenous variables $\left(c_{t}^{y}, c_{t}^{o}, k_{t}, w_{t}, r_{t}\right)$, given the government's social security policy, which are characterized by a pair of the tax rate $\left(\theta_{t}\right)$ and the dynamic path of the trust fund $\left(k_{t}^{s}\right)$. For simplicity, we first concentrate on the steady state with all endogenous variables constant over time (expressing those values with no suffix $t$ ). In addition, we assume that the government, the social planner, has a social utility function that is defined over the individual utility functions, with $R$ as the government's rate of time preference. It is widely known that the necessary condition for the social optimum is expressed by the modified golden rule, which is given by $1+r=(1+R)(1+n)$. The case with $R=0$ corresponds to the golden rule, which requires that $r=n^{4}$.

\footnotetext{
${ }^{4}$ We discuss the modified golden rule rather than the (not modified) golden rule, because
} 
In the long run, the government aims to establish an optimal social security program to achieve this modified golden rule. It searches for the optimal pair of tax rate and trust fund, both of which are assumed to be constant over time $\left(\theta_{t}=\theta, k_{t}^{s}=k^{s}\right)$. It should be noted that this optimal pair is a continuum of solutions rather than a unique solution, as the government aims to achieve one policy goal with two policy tools. If a combination of no trust fund and a positive tax rate is shown to satisfy the modified golden rule, a pure PAYGO system that has no trust fund could be justified. A combination of a positive trust fund and no taxes, which means the government finances social security benefits only from the interest on the trust fund inherited from the past, cannot be ruled out. Also, the cases of a negative tax rate (and correspondingly negative benefits), of a negative trust fund (which means the trust fund borrows money from the private sector), or even of the trust fund exceeding total capital (which means the private sector borrows money from the trust fund) are theoretically possible, although they do not seem to be plausible.

\subsection{The optimal social security program in a steady state}

To make the model easier to manipulate algebraically, we apply a log-linear utility function, $u_{t}=\ln c_{t}^{y}+(1+\delta)^{-1} \ln c_{t+1}^{o}$ and a Cobb-Douglas production function, $y_{t}=k_{t}^{\alpha}(0<\alpha<1)$, in which $\alpha$ denotes a capital share, to (2) and (8), respectively. A Cobb-Douglas production function implies a unit elasticity of factor substitution, but the main results remain the same in a more general case with a CES technology, as suggested by Bohn (2001)'s discussions. Simple calculations based on (3), (7), (8), and (9) yield the steady state under the modified golden rule, which can be expressed by

population growth rate is likely to be negative with an aging population, thus the interest rate must be negative to achieve the golden rule, which does not seem to be realistic. 


$$
\begin{aligned}
& c^{y}=\frac{1+\delta}{2+\delta}\left[\left(1-\frac{R}{1+R} \theta\right) w+\frac{R}{1+R}(1+n) k^{s}\right], \\
& c^{o}=\frac{(1+R)(1+n)}{1+\delta} c^{y}, \\
& k^{s}=k-\frac{1}{1+n}\left[(1-\theta) w-c^{y}\right]
\end{aligned}
$$

where

$$
k=\left[\frac{(1+R)(1+n)-1}{\alpha}\right]^{1 /(\alpha-1)},
$$

and

$$
w=(1-\alpha) k^{\alpha} .
$$

These endogenous variables are determined solely by population growth rate, $n$, which is given exogenously in our model, along with parameters.

From the equation system stated above, we implicitly obtain the optimal social security program, which is expressed as a combination of the arbitrarily given tax rate and the trust fund:

$$
k^{s}=\frac{(1+R)[(2+\delta)(1+n) k-w]}{(R+\delta+2)(1+n)}+\frac{\theta w}{1+n} .
$$

The optimal level of the benefit, $b$, is solved by

$$
b=(1+n)\left[\theta w+(r-n) k^{s}\right]=(1+n)\left[\theta w+(1+n) R k^{s}\right],
$$

from (5) and $(10)^{5}$, meaning that social security benefits are financed by taxes and net

${ }^{5}$ If the government intends to achieve the (not modified) golden rule, the conditions (10) and (11) would be simplified by $R=0$ to:

$$
k^{s}=k-\frac{1-(\delta+2) \theta}{(\delta+2)(1+n)} w, b=(1+n) \theta w .
$$

These conditions imply that a PAYGO system, which equates taxes and benefits in each period, can achieve the golden rule, if the government sustains the trust fund at a level that is sufficient 
interest on the trust fund.

Three points are noteworthy regarding the optimal level of the trust fund, which is expressed by (10). First, a higher tax rate will need a larger trust fund. This seems to make sense intuitively, because the government may want to offset the negative impact on private savings of a PAYGO system (given an aging population) using the higher interest on the trust fund.

Second, simple calculations can show that lower population growth will need a larger trust fund, with the tax rate given, unless the tax rate is very low. This also seems plausible, because lower population growth tends to strengthen the adverse demographic pressures through a PAYGO system, and such pressures should be mitigated using interest on the trust fund to finance pension benefits.

Third, a pure PAYGO system, which is characterized by the combination of $\theta>0$ and $k^{s}=0$, would be feasible as far as $(2+\delta)(1+n) k<w$. This condition is rewritten as

$$
\alpha<\frac{(1+R)(1+n)-1}{(R+\delta+3)(1+n)-1}
$$

given a Cobb-Douglas production function. This inequality is less likely to hold with a lower $n$, implying that an aging population makes a pure PAYGO system less acceptable, in line with the conventional view.

Now, we illustrate the optimal social security program and show how it is affected by population growth, based on simple calibrations. We compare the three cases for population growth ( $n=-0.01,0$, and 0.01 at an annual rate), tentatively assuming that $\alpha=0.3$, $\delta=0.02$, and $R=0.03^{6}$. Figure 1 summarizes the results. The horizontal axis shows the tax rate, and the vertical axis shows the level of trust fund required to achieve the modified

to completely offset the negative impact on private savings of a PAYGO system.

${ }^{6}$ For calculations, we take thirty-year composite rates for $n, R$ and $\delta$, because our model is a two-period life-cycle model. 
golden rule with the corresponding tax rate. Three lines plot the optimal combinations of the tax rate and the trust fund, respectively corresponding to three different population growth rates.

This figure confirms the two points mentioned above. First, with a lower population growth it will become more difficult to justify a pure PAYGO system that has no trust fund; for instance, the line of $n=-0.01$ crosses the horizontal axis at a tax rate of about -0.07 . This is because a PAYGO system tends to subdue capital accumulation given an aging population. Second, lower population growth needs a larger trust fund to achieve the modified golden rule, as suggested by the lines with lower/negative population growth located at the upper left part of the figure. With lower population growth, the government has to offset the negative impact of a PAYGO system on national savings by holding a larger trust fund.

Figure 2 presents the results of a sensitivity analysis to examine how the optimal social security program is sensitive to assumptions about the private and social rates of time preference, that is, $\delta$ and $R$. We assume no population $(n=0)$ as the benchmark case, and consider four combinations of the private and social rates of time preference: $(\delta, R)=(0.02$, $0.02) ;(0.02,0.03) ;(0.03,0.02) ;(0.02,0.02)$ at an annual rate.

Two points should be noted from this figure. First, a higher social rate of time preference needs a smaller trust fund, given the same tax rate. The government has less incentive to build up the trust fund if it is not concerned about the utility of future generations. This might be likely the case in a democratic society, where future (or younger) generations have no vote. Second, a higher private rate of time preference leads to a larger trust fund. If the individual discounts his/her future utility at a higher rate, private savings will be more likely to be considered too low and the government instead will have to raise public savings to support capital accumulation. 


\subsection{A small open economy}

The optimal social security program would look quite different if we assume a small open economy in which wage and interest rate are exogenously given. In a small open economy, the government does not need to worry about the impact of social security policies on aggregated capital accumulation, and thus the (modified) golden rule is irrelevant. The government can concentrate on maximizing the net lifetime income of the representative individual in the long run. The representative individual's budget constraint (7) can be simplified to

$$
c^{y}+\frac{c^{o}}{1+r}=w+\frac{n-r}{1+r}\left[\theta w-(1+n) k^{s}\right] .
$$

Hence, if the population growth rate is higher than the interest rate, a pure PAYGO system is optimal, although the optimal tax rate is indeterminate. This is because the rate of return to a pure PAYGO system (which is equal to $n$ ) exceeds the rate of return of the trust fund (which is equal to $r$ ).

In contrast, if the rate of population growth is less than the interest rate, a pure PAYGO system cannot be justified and the government should hold a trust fund of $\theta w /(1+n)$ or more. This minimum level of the trust fund is exactly enough to offset the negative impact of a PAYGO system on the individual's lifetime income under an aging population. And, the pension benefit that corresponds to this minimum trust fund is $(1+r) \theta w$, which is the same as the level in a fully funded system. This means that the optimal social security program is neutral to the individual's lifetime budget constraint, and it is effectively the same as a funded system or even no social security system.

\section{The trust fund and demographic shocks}




\subsection{An overview}

This section examines how social security programs should respond to demographic shocks, if they can make use of the trust fund. First, we confirm that the impact on the economy of demographic shocks depends heavily on model settings. There is a widespread view that a PAYGO system makes a smaller cohort worse off because it must face higher taxes to finance benefits already committed to a retired generation. This argument seems to be reasonable if we are in a small open economy, where wage and interest rates are given exogenously. To absorb the adverse impact of this demographic shock, the government would temporarily use the trust fund to keep the tax rate from rising.

It should be noted, however, that subsequent generations will receive less interest on the trust fund than otherwise would be the case, and eventually face higher taxes and/or lower benefits to keep social security finances balanced. The government thus will face a trade-off of economic welfare between different generations, and management of the trust fund can lead to a distributional debate. Generally, the more the government discounts the utility of future generations, the more it will tend to rely on temporary adjustments to the trust fund. This kind of discussion has often, but implicitly, appeared in recent debates on social security reforms in Japan.

A closed economy provides a quite different picture. A PAYGO system can be interpreted as social insurance for intergenerational risk sharing, as stressed by many researchers including Smith (1982) and Bohn (2001). A PAYGO system, especially with defined benefits, would partly offset the factor-price effects caused by demographic shocks. A cohort whose population size happens to be smaller than previous ones is expected to see a higher capital-labor ratio and wage income, so it can afford to transfer income to other generations through a PAYGO system. If positive factor-price effects exceed negative income effects due to higher taxes, a small cohort will become better off on a net basis, even 
under a PAYGO system. This aspect of a PAYGO system sometime gets lost in the debate on the effects of demographic changes on social security programs. As suggested by the above discussions, however, the net results rely heavily on parameters; a higher tax rate is likely to make the negative impact larger, while a higher labor share is expected to raise the positive impact.

Hence, in contrast with the case of a small open economy, the desirable policy response to demographic shocks depends on which are larger, the factor-price effects or the negative income effects of a PAYGO system in a closed economy. If the positive factor-price effects dominate, a reduction of the trust fund is likely to further raise the utility of a small cohort that enjoys higher wage income, with a reduction in the interest income available to future generations. Raising taxes on the small cohort, which can enjoy higher wage income, could allow the government to retain the trust fund to subdue the spillover of the shocks to subsequent generations. On the contrary, if the negative impact of a PAYGO system on a small cohort dominates, then reducing the trust fund may lessen the adverse impact on that cohort. In this case, however, it should be remembered that subsequent generations will receive lower or no interest on the trust fund.

\subsection{Policy responses to temporary demographic shocks}

The discussions in the previous section suggest that the desired policy response to demographic changes is quite different in a small open economy and a closed economy. In a small open economy, the government can temporarily use the trust fund to alleviate the shock on a small cohort, although it will face a trade-off of economic welfare between different generations. In a closed economy, the government should take into account the positive factor-price effects on a small cohort, and the case that it should put additional taxes on a small generation cannot be ruled out. This section compares policy responses to a 
temporary demographic shock using simple calibrations. We believe that the analysis in this section, even if much simplified, helps provide an understanding of the economic role of the trust fund.

We set $\alpha=0.3$ and $\delta=0.02$, and $R=0.03$ for calibrations. And we assume that the economy stays in a steady state that satisfies the modified golden rule with no population growth, with two types of social security programs: one is a pure PAYGO system with no trust fund, and the other is a PAYGO system with a trust fund. In the former program, the tax rate and the benefit are calculated as $8.9 \%$ and 0.032 (equivalent to $11.5 \%$ of the wage of young workers), respectively, putting $k^{\mathrm{s}}=0$ into (10) and (11). In the latter program, we tentatively set the tax rate to be $10 \%$, which makes the trust fund 0.00386 (equivalent to $3.6 \%$ of total capital stock) and the benefit 0.0414 (equivalent to $11.5 \%$ of the wage), by putting $\theta=0.1$ into (10) and (11). In a small open economy, we assume that aggregated capital stock remains fixed at the same level as that in this steady state in a closed economy for the purpose of comparison. For all these cases, total capital stock is initially equal to 0.0177 .

We assume that the population growth rate happens to decline from $0 \%$ to minus $1 \%$ at an annual rate for generation 1 , and then returns to $0 \%$, to trace spillover effects of a temporary demographic shock and policy responses to it. And, we consider the following three policy options:

Option A: to have no trust fund and raise the tax rate for generation 1;

Option B: to have a trust fund and raise the tax rate for generation 1 (and keep the fund unchanged);

Option C: to have a trust fund and reduce it, followed by an increase in the tax rate, within a PAYGO framework, in response to a temporary reduction of the population growth rate, in both open and closed economies. Generally speaking, the government has three 
policy variables to adjust: the tax rate, the benefit, and the trust fund. We first assume that the government keeps the benefit unchanged and adjusts one of the remaining two to keep the social security finances balanced. However, adopting option $C$ is likely to exhaust the trust fund sooner or later, because tax revenue will fall short of the level needed to finance benefits. Thus, option $\mathrm{C}$ requires the government to raise the tax rate, once the trust fund is exhausted. If the government does not adjust the tax rate to keep social security finances balanced, the trust fund is likely to decrease cumulatively and make the economy unstable, as indicated by (5).

If the government can choose to adjust the level of benefits rather than the tax rate, we consider another set of three policy options; that is,

Option $A^{\prime}$ : to have no trust fund and reduce the benefit for generation 0 ;

Option B': to have a trust fund and reduce the benefit for generation 0 (and keep the fund unchanged);

Option C': to have a trust fund and reduce it, followed by a reduction of the benefit, where generation 0 is the generation retiring when generation 1 works.

Table 1 summarizes the results of these six policy options, focusing on how the tax rate, the benefit, and the trust fund are affected to them. And Figures $3 \mathrm{a}$ and $3 \mathrm{~b}$ demonstrate the impacts on each generation's utility of these policy options in a small open economy. To begin with, let us compare options A, B, and C in Figure 3a. For option A, the government temporally raises the tax rate to $12.1 \%$ for generation 1 from the original $8.9 \%$. This option reduces net lifetime income and utility of generation 1 , but it keeps those of subsequent generations unchanged. Option B, which assumes the government has a trust fund and keeps it at the current level, leads to almost the same result as option A. The tax rate is raised to $13.8 \%$ from the original $10 \%$ for generation 1 , on which the negative impact of the shock concentrates. The negative impact on generation 1 is somewhat 
smaller in option A than in option B. In option B, generation 1 must pay more additional taxes than in option A, since it has to avoid the negative impact from spilling over to the subsequent generations via the trust fund.

By contrast, option $\mathrm{C}$ intends to absorb the demographic shock using the trust fund, but it fails to do so because it exhausts the fund immediately, and makes subsequent generations no longer able to rely on the interest on the fund. To keep social security finances balanced, the government has to raise the tax rate to $11.5 \%$ from $10 \%$. This option thus lowers lifetime income and utility of subsequent generations. Accordingly, the government would choose between $\mathrm{A}$ and $\mathrm{C}$, and this choice leads to a distributional debate; generation 1 prefers option $\mathrm{C}$ most and option $\mathrm{A}$ least, whereas subsequent generations value option $A$ as best and option $C$ as worst. The decision depends on how the government respects the utility of future generations, and the case of choosing option C and making use of the trust fund as a buffer can be possible.

If the government can adjust the level of benefit, options A', B', and C' are available. Options $A^{\prime}$ and $B^{\prime}$ intend to make generation 0 absorb the demographic shock, whereas option $C^{\prime}$ intends to use the trust fund as a buffer. Options $A^{\prime}$ and $B^{\prime}$ require a reduction of the benefit to 0.0237 from the original 0.0320 , and to 0.0314 from the original 0.0414 , respectively, for generation 0 as seen in Table 1, and reduce the utility of that generation, keeping the utility of subsequent generations unchanged as seen in Figure 3b. Option C' sustains the benefit for generation 0 by reducing the trust fund, but it has to trim the benefit to 0.0359 for subsequent generations, because the trust fund is exhausted. Here, again, the choice of policy options leads to a redistribution issue, and whether option C' is accepted or not depends on how much the government puts importance on the utility of future generations. Also, judging from the comparison of Figures $3 a$ and $3 b$, adjusting the benefit rather than the tax rate would smooth the demographic shock more effectively. 
Figures $4 \mathrm{a}$ and $4 \mathrm{~b}$ illustrate the results for a closed economy, with the same assumptions and demographic shock as in a small open economy. In the case of option A, which assumes a pure PAYGO system, the tax rate is required to be raised to $11.1 \%$ from the current $8.9 \%$ for generation 1 in the face of reduced birthrates. More importantly, as seen in Figure 4a, the factor-price effects more than offset the negative impact of a tax hike, leaving generation 1 better off on net. In addition, some subsequent generations can enjoy a spillover of the positive factor-price effects, which accelerate capital accumulation and in turn raise their lifetime incomes. Generation 0 becomes worse off, because a higher capital-labor ratio reduces the interest income it receives after retirement.

Having a trust fund but keeping it unchanged, option B calls for a rise in the tax rate to $12.7 \%$ from the current $10 \%$ for generation 1 . This makes the utility of generation 1 and subsequent generations lower than the levels in option $\mathrm{A}$, but not much. Option $\mathrm{C}$, which reduces the trust fund to avoid a tax hike for generation 1 , raises the utility of that generation further, as well as the utility of some subsequent generations, although it lowers that of future generations. In option $\mathrm{C}$, generation 1 can receive nearly all of the positive factor-price effects without additional tax payments. Future generations, however, can receive no interest on the trust fund, thus they have to pay higher taxes; the tax rate will be raised up to $11.8 \%$ from the original $10 \%$. The choice is thus likely to be one between options $\mathrm{A}$ and $\mathrm{C}$, again, and it leads to a redistribution issue. Compared to the case of a small open economy, however, choosing option $\mathrm{C}$ is more problematic. It raises the utility of generation 1, which enjoys the positive factor-price effects and whose utility is higher than its level before the shock, at the expense of future generations. We should also note that compared to options A and C, option B can more successfully smooth the shock.

The choice among options A', B', and C'-which allow the government to adjust the benefit rather than the tax-also can be assessed in terms of intergenerational equity (see 
Figure $4 b)$. Options $A^{\prime}$ and $B^{\prime}$ require a reduction of the replacement ratio for generation 0 to $6.6 \%$ from the original $8.9 \%$, and to $8.4 \%$ from $11.5 \%$, respectively. Option C' uses the trust fund to keep the benefit for generation 0 at the original level, but exhausts it soon and eventually calls for a reduction in the benefit to 0.0359 from the original 0.0414 . With option $A^{\prime}$, the negative impact of the shock is concentrated on generation 0 . With option $C^{\prime}$, the trust fund fails to fully absorb the shock, and future generations become worse off because they face a reduction in benefits and can no longer rely on interest on the trust fund. Option B', which keeps the trust fund unchanged and calls for an adjustment of the benefit, moderates the shock most successfully; it holds down a reduction of the utility of generation 0 , subdues a rise of the utility of generation 1 (which enjoys positive factor-price effects), and avoids the shock from spilling over to future generations.

To sum up, in both small open and closed economies, the choice between using the trust fund as a buffer and adjusting the tax rate or the benefit in the face of a temporary demographic shock leads to a distribution debate. Using the trust fund cannot fully isolate subsequent generations from a demographic shock, because a change in the level of the trust fund affects social security finances, and requires the government to adjust the tax rate and/or the benefit to keep the finances balanced. Compared to a small open economy, a closed economy makes it more problematic to utilize the trust fund, since that option could even lead to a widening of intergenerational inequality. In closed economy, to have the trust fund but adjust the tax rate or benefits to keep the fund unchanged is expected to moderate the shock most successfully. Also, as suggested by Figures 3 and 4 , using the trust fund as a buffer makes the economy deviate from the modified golden rule path over time and reduces the economic welfare of future generations.

\subsection{Policy responses to long-term demographic shocks}


Section 2 discussed the optimal combination of the trust fund and the tax rate in a steady state with constant population growth, and the previous sections in this section examined policy responses to a temporary demographic shock. Unfortunately, policy implications of either of these two analyses are limited, because the economy is not always in a steady state and population growth rate is likely to continue falling over the next decades, with no pickup in birthrates in prospect. However, it seems to be nearly impossible to algebraically solve the optimal social security programs with a drifting rate of population growth.

Hence, we roughly and qualitatively examine how the government should respond to a long-term shift of a steady state, based on the previous discussions; more specifically, we consider policy responses to a shift from a steady state with high or positive population growth to the one with low or negative population growth (in both states the population growth rate is assumed to be constant). We call these state $\mathrm{H}$ and state $\mathrm{L}$, respectively. A shift from state $H$ to state $L$ roughly reflects the long-term demographic trend observed in Japan and many industrialized nations. As a baseline situation, we also assume that in both states the government applies a PAYGO system with the same tax rate.

We start with a small open economy. In state L, a PAYGO system will be under stronger demographic pressures than in state $\mathrm{H}$ and, other things being equal, the utility of people in state $\mathrm{L}$ will be lower than in state $\mathrm{H}$, even if they both live under the modified golden rule. Also, as indicated in section 2 , state $L$ can reduce stronger demographic pressures with a larger trust fund. If, towards the end of state $\mathrm{H}$, the government built up the trust fund to a higher level than required to achieve the modified golden rule in state $\mathrm{H}$, it could transfer the trust fund to state $L$ for the initial level of the trust fund to alleviate the demographic pressures.

To do so, people in state $\mathrm{H}$ would pay higher taxes and/or to receive lower benefits than on the path that satisfies the modified golden rule. This would help to maintain 
intergenerational equity. Trust fund management thus is determined by the government's judgment on intergenerational equity; the more importance the government puts on the welfare of people in state $\mathrm{H}$, the larger the trust fund it will want to accumulate in state $\mathrm{H}$, and vice versa.

The government will face quite a different situation in a closed economy, as already suggested by the discussions on policy responses to a temporary demographic shock. On one hand, a larger trust fund is necessary for state $L$ to achieve the modified golden rule. On the other hand, people in state $L$ will be able to enjoy a higher level of utility than those in state $\mathrm{H}$, because they face a higher capital-labor ratio and correspondingly higher wage income. Hence, it is difficult for the government to justify transferring the trust fund from state $\mathrm{H}$ to state $\mathrm{L}$, because it would add to the welfare of people in state $\mathrm{L}$, who already enjoy positive factor-price effects, and at the same time it would reduce the welfare of people in state $\mathrm{H}$. In terms of intergenerational equity, the government should reduce the trust fund towards the end of state $\mathrm{H}$ by reducing taxes and/or increasing benefits, thereby transferring income backward from people in state $L$ to those in state $H$.

Therefore, the trust fund policy depends much on where we live. In a small open economy, it can be interpreted as an income redistribution policy between generations, and raising the trust fund for future generations who are expected to be under accelerated demographic pressures can be justified in terms of intergenerational equity. In a closed economy, by contrast, increasing the trust fund is likely to widen the inequality of income and welfare between current and future generations.

In the latter case, another policy option may be to downsize a PAYGO system in state $\mathrm{L}$ by reducing the tax rate (and correspondingly level of benefits) without raising the level of the trust fund. Indeed, Figure 3a shows that when the population growth rate decreases, lowering the tax rate, given that the level of the trust fund is unchanged, would sustain the 
modified golden rule. This option is Pareto improving, because it can raise the utility of people in state $\mathrm{L}$, while keeping that of people in state $\mathrm{H}$ unchanged.

\section{Implications for social security reforms in Japan}

\subsection{Pension Reform}

Japanese social security programs can be described basically as a defined-benefit PAYGO program, although they have accumulated big surpluses in an accounting trust fund. Traditionally, the MHLW first sets the level of the average benefit, which is considered to be reasonable relative to the average wage of young workers, and then it adjusts the tax rates as well as the path of the trust fund to finance the aggregated benefits. This system tends to be vulnerable to macroeconomic and demographic conditions, as well as their prospects. Actually, the MHLW has repeatedly revised the scheduled path of tax hikes upward in past reforms, because the official projections of fertility and wage income growth have consistently turned out to be over-optimistic.

In the 2000 Pension Reform, the MHLW called for a gradual increase in the social security tax rate from $13.58 \%$ to $19.8 \%$ to sustain the replacement ratio at $59 \%$ over the next decades, with the total fertility rate officially expected to recover to 1.61 by 2050 . However, the new official population projections released in 2002 forecast that the total fertility rate will pick up to only 1.39. Correspondingly, the scheduled increase in the tax rate incorporated in 2000 Reform has turned out to be insufficient to keep the finances balanced. To keep the committed level of benefits and avoid exhausting the trust fund, the tax rate has to be raised to $22.4 \%$ according to the MHLW's revised projections.

Moreover, the Japanese social security system has huge net pension liabilities, which are defined as promised benefits that are not covered by the existing trust fund. The 
updated balance sheet of the public sector, which was released by the Ministry of Finance (MOF) in 2003, shows that the present value of the promised benefits in the EMI program was 725 trillion yen at the end of fiscal 2001. This is well above the trust fund of 172 trillion yen $^{7}$, indicating that the government has net pension liabilities of 553 trillion yen. A huge trust fund tends to hide serious issues related to the sustainability of net pension liabilities, which are likely to continue growing as demonstrated by Oshio (2003)'s simulations. Indeed, the MOF estimates show that net pension liabilities will increase by 52 trillion yen in the future, if the government keeps the existing social security programs.

Rising concerns about the financial sustainability of the social security system, as well as widening intergenerational inequality, have led to debates regarding 2004 Pension Reform. These debates center on, among others, two issues that are closely related to the management of the trust fund. The first is the introduction of the "fixed tax method" (Hokenryo Kotei Hoshiki), which claims that the tax rate is fixed (after reaching $18.35 \%$ ), and that the benefit is adjusted to keep social security finances balanced, to avoid a further increase in tax rate and net pension liabilities. This method is similar to, if not the same as, the automatic balance system introduced in Sweden in 2001, and differs substantially from the previous system in which the benefit is determined first and the tax rate is adjusted. The second is about the use of the trust fund, which is now equivalent to about five years of benefits. A reduction of the trust fund can be expected to avoid taxes from rising and/or benefits from decreasing, but its depletion will reduce the fund available for the benefits of future generations. We discuss these two issues, and assess the potential impact of the proposed reforms, based on the discussions in the previous sections.

\footnotetext{
${ }^{7}$ This amount includes what is called the Daiko part, the fund held by private firms on behalf of the government.
} 


\subsection{The fixed tax method}

Introducing the fixed tax method affects the dynamics of the trust fund and net pension liabilities. This method means that overall benefits are automatically adjusted within the cash revenue in each period. We can consider two versions of this method, which we discuss in this section within the framework of the simple two-period model presented in section 2 .

The first version (referred to as version I) is to make the total benefits equal the sum of tax revenue and interest on the trust fund in each period. Then, we have

$$
b_{t} L_{t-1}=L_{t} \theta w+r L_{t} k_{t}^{s}
$$

or in per capita terms,

$$
b_{t}=\left(1+n_{t}\right)\left(\theta w+r k_{t}^{s}\right)
$$

where wage and interest rates are set to be constant. Then, from (4) and (5), the dynamics of the trust fund are given by

$$
L_{t} k_{t}^{s}=L_{t-1} k_{t-1}^{s}
$$

or

$$
k_{t}^{s}=\frac{k_{t-1}^{s}}{1+n_{t}},
$$

which means that the nominal value of the aggregate trust fund is kept unchanged.

The second version (referred to as version II) is to determine the benefit in such a way that

$$
b_{t} L_{t-1}=L_{t} \theta w_{t}+\left(r_{t}-n_{t+1}\right) L_{t} k_{t}^{s} .
$$

This means that, for instance, a generation that bears a smaller number of children than its own cohort size will give additional benefits to the parent generation rather than leaving capital stock to the child generation, which would otherwise receive a higher per-capita trust fund; that is, both children and grandchildren support grandparents. In per capita terms, 
the benefit can be rewritten as

$$
b_{t}=\left(1+n_{t}\right)\left[\theta w_{t}+\left(r_{t}-n_{t+1}\right) k_{t}^{s}\right]
$$

Combined with (5), this keeps the per capita trust fund constant over time; that is,

$$
k_{t}^{s}=k_{t-1}^{s} \text {, }
$$

suggesting that version II corresponds to option B' in section 3.2.

Two effects are expected from the fixed tax method. The first is to alleviate demographic pressures by avoiding a smaller cohort paying higher taxes and making a larger cohort receive lower benefits. The second is to avoid net pension liabilities from accumulating from the current level, which has already reached a seemingly prohibitive level. If total benefits are automatically adjusted to the sum of tax revenue and interest on the fund each year, net pension liabilities are expected to remain controllable.

As far as the first effect is concerned, it is ambiguous whether or not this can be realized. It depends on whether we live in a small open or closed economy, as suggested in the discussions in section 2.2. In a small open economy, adjusting the benefit can be justified in terms of intergenerational equity, because it subdues income transfer from a lower income cohort to a higher income cohort. And version I is more desirable than version II, because the former raises the per-capita trust fund for a smaller cohort as indicated by (13). When it comes to a closed economy, it should be remembered that a smaller cohort can get positive factor-price effects. Introducing the fixed tax method, which is intended to shift negative demographic pressures caused by a PAYGO system to a larger cohort from a smaller one, is controversial. Moreover, contrary to the case of a small open economy, version II adds to factor-price effects that work in favor of a smaller cohort, whereas version I does not ${ }^{8}$. In addition, version II, which corresponds to option B' in

\footnotetext{
${ }^{8}$ Versions I and II show differing impacts on capital accumulation in a closed economy. For version I, the dynamic path of the trust fund (13) implies that in the steady state $k_{t}^{s}=0$
} 
section 3.2 , is expected to help effectively moderate the demographic shock over time.

Next, we consider the second effect. Can the fixed tax method bring net pension liabilities under control? In our simple two-period model, the relationship between trust fund and net pension liabilities can be expressed by

$$
L_{t+1} d_{t+1}=\frac{L_{t} b_{t+1}}{1+r_{t+1}}-L_{t+1} k_{t+1}^{s}
$$

or in per-capita terms,

$$
d_{t}=\frac{b_{t}}{\left(1+n_{t}\right)\left(1+r_{t}\right)}-k_{t}^{s}
$$

where $d_{t}$ denotes net pension liabilities at the beginning of period $t$. The government promises young workers in period $t$ to pay $L_{t} b_{t+1}$ in total in period $t+1$, and the fund available at the beginning of period $t+1$ is $L_{t+1} k_{t+1}^{s}$. Hence, net liabilities are equal to the discounted value of the former less the latter.

Plugging (16) into (5) leads to the dynamic equation of net pension liabilities, which is expressed in per-capita terms by

$$
d_{t+1}=\frac{1}{1+n_{t+1}}\left[\left(1+r_{t}\right) d_{t}-\theta w_{t}+\frac{b_{t+1}}{1+r_{t+1}}\right] .
$$

This equation suggests that the dynamic path of net pension liabilities tends to be unstable if the population growth rate is below the interest rate, like that of the trust fund indicated in (5). Moreover, the risk that net pension liabilities will explode cannot be ruled out, especially if the government keeps promising the workers too high a level of pension benefits to be

(provided population growth rate is not zero) and correspondingly $b_{t}=\left(1+n_{t}\right) \theta w$. This combination of $k_{t}^{s}=0$ and $b_{t}=\left(1+n_{t}\right) \theta w$ corresponds to a pure PAYGO system, which is not optimal in general as shown in section 2.1. In the case of version II, the per-capita trust fund is fixed as shown by (15) and the government can set its level to achieve the modified golden rule so that (11) holds, given the tax rate. 
financed by their own taxes $\left(b_{t+1}>\left(1+r_{t+1}\right) \theta w_{t}\right)$ under an aging population. The existing high level of net pension liabilities in Japan implies that the government has been promising people too much pension benefits, which leads to an accumulation of tax burdens levied on future generations.

The fixed tax method affects the dynamic path of net pension liabilities. In the case of version I, which is given by (12), plugging (12) into (16) yields

$$
d_{t+1}=\frac{1}{\left(1+n_{t+1}\right)\left(1+r_{t+1}\right)}\left[\left(1+r_{t}\right) d_{t}-\theta w_{t}+\left(1+n_{t+1}\right) \theta w_{t+1}\right]
$$

which looks more stable than the general shape of the dynamic path in (17), judging from the comparison of the coefficients on $d_{\mathrm{t}}$. And an explosion of net pension liabilities becomes less likely, because its dynamic path is not affected by arbitrarily determined benefits. In addition, in the steady state, we have $d=\theta w /(1+r)$, which is a pure PAYGO system of $b=(1+n) \theta w$ and $k^{s}=0$.

In the case of version II, which is given by (14), net pension liabilities follow the dynamic equation

$$
d_{t+1}=\frac{1}{\left(1+n_{t+1}\right)\left(1+r_{t+1}\right)}\left[\left(1+n_{t+2}\right)\left(1+r_{t}\right) d_{t}-\left(1+n_{t+2}\right) \theta w_{t}+\left(1+n_{t+1}\right) \theta w_{t+1}\right]
$$

obtained by plugging (14) into (16). This path appears to be more stable than in the case of version I (see (18)), with negative population growth. In the steady state, the level of net pension liabilities is implicitly determined by trust fund and taxes (and benefits), which are set by the government to achieve the modified golden rule.

\subsection{Use of the trust fund}

Many observers criticize the government for having an excessive trust fund, and that it should reduce it in response to accelerating demographic pressures. However, 
management of the trust fund is closely related to income redistribution between current and future generations. A reduction of the trust fund is expected to reduce taxes or increase benefits for current generations, whereas it will reduce the interest on the trust fund for future generations. Recently, Sakaguchi (2003), Minister of Health, Labor, and Welfare, released a report on how the trust fund strategy will affect the level of benefits. If the government sustains the trust fund to keep social security balances eternally, the replacement ratio will fall to $52.8 \%$ from the current $59 \%$ (assuming that the tax rate will be raised gradually to $20 \%$ from the current $13.58 \%$ ). If the government reduces the fund to a level equivalent to one year of benefits by 2100 , the replacement ratio will become $54.5 \%$, which is somewhat higher than the former case, but it implies an increase of net pension liabilities which future generations have to pay.

The discussions on policy responses to long-term demographic shocks in section 3.4 have direct implications for this issue. If we ignore price-factor effects, trust fund management leads to income redistribution between generations. Keeping the trust fund at a level that is higher than optimal for current generations would reduce the adverse impacts of accelerated aging on future generations through a PAYGO system. Indeed, Hatta and Oguchi (1999) insist that the government should make the baby boom generation pay additional taxes before retirement to finance their own benefits.

However, if future generations can enjoy higher per capita capital stock and lifetime utility than current generations, it would be possible to reduce the trust fund in order to lower taxes and/or raise benefits. Most social security projections, including those conducted by MHLW and other public/private institutions, take wage and interest rates as exogenously given, implicitly assuming a small open economy. Thus, the trade-off in the impact on the utility depicted by their projections is overemphasized to some extent. If factor-price effects are taken into account, it would be more difficult to justify the current high level of the trust 
fund.

\section{Concluding remarks}

We have investigated why and to what extent the government needs the trust fund in social security policies, and how it should manage the fund in the face of demographic shocks, based on a simple overlapping-generations model. We have two major results. First, given an aging population, a government can achieve the (modified) golden rule or offset the negative income effect of a PAYGO system by having a trust fund. The optimal level of the trust fund is positively related to the rate of social security tax and negatively related to the rate of population growth. A pure PAYGO system and a fully funded system generally fail to optimize social welfare. Second, in a closed economy, using the trust fund as a buffer for demographic shocks could lead to wider intergenerational inequality by adding to the utility of a small cohort, which enjoys positive factor-price effects, at the expense of other generations. In addition, the trust fund cannot fully absorb demographic shocks, because the interest on it will change and affect the utility of subsequent generations.

We have also discussed the policy implications of these results for the social security reform debate in Japan, focusing on an introduction of the fixed tax method and the use of the trust fund. The fixed tax method, which basically aims to contain aggregate benefits within tax revenue and the interest on the trust fund, has a larger negative effect on intergenerational equity in a closed economy than in a small open economy. However, this method can to some extent help avoid net pension liabilities from exploding given an aging population. The use of the trust fund in response to accelerated aging is to some extent a distribution issue, but it depends on where we live. A reduction of the fund is more likely to be justified in a closed economy than in a small open economy, if future generations can 
enjoy positive factor price effects due to a smaller population size.

Our analysis has several limitations and reservations. Most of all, the factor-price effects might be overstated in this paper. Our two-period OLG model seems to be biased towards emphasizing those effects, since it assumes that the young has only labor income and the old has only capital income, and it neglects the labor market where different cohorts compete with each other. Actually, some Auerbach-Kotlikoff-style simulation studies on the transition path to an aging Japan, such as Kato (1998) and Uemura (2001), find mixed effects of a cohort size on the utility assuming a closed economy. A more careful analysis with a multi-period OLG models are needed in order to correctly assess the magnitude of the factor-price effects. The actual relevance of those effects should be judged by empirical studies ${ }^{9}$, although it is difficult to get time-series data of sufficient length and stationarity to allow credible statistical inferences.

Secondly, policy implications tend to depend heavily on the "initial state." If the social security is not a "matured" PAYGO system, discussions in terms of intergenerational equity becomes more complicated. The government may have promised the current elderly (and even the old working generations) to give them more benefits than their own tax payments, and postponed burdens will at least partly offset the factor-price effects which future generations are expected to enjoy. If that is the case, reducing the trust fund may adversely affect intergenerational equity.

In addition, there remain many Japan-specific, institutional issues yet to be addressed. Most of all, as correctly pointed out by Tamaki (2003), interdependency and transparency of fund management, as well as ownership problems, are serious issues, especially if the government continues to invest the trust fund in private stocks as well as government bonds.

\footnotetext{
${ }^{9}$ There is not a large literature examining how a cohort size affects wages and asset returns in Japan, but Genda (1997) finds that Japanese baby boomers face a negative cohort effect on wages.
} 
In addition, although we implicitly assume that the trust fund and private capital are perfectly substitutable, it is more realistic to assume that the trust fund is used less efficiently than private capital. Most of the trust fund has been invested in or lent to inefficient government institutions via the Fiscal Investment and Loan Program. These issues should be explicitly taken into account to make discussions about trust fund management more relevant and realistic. 


\section{References}

Aaron, H. J. and R. D. Reishauer (1998) Countdown to Reform, Century Foundation Press, New York.

Abel, A.B.(2001) "The social security and trust fund, the riskless interest rate, and capital accumulation," in J. Y. Campbell and M. Feldstein ed., Risk Aspects of Investment-based Social Security Reform, The University of Chicago Press, Chicago, pp.153-193.

(2003) "The effects of a baby boom on stock prices and capital accumulation in the presence of social security," Econometrica, 71, pp. 551-578.

Bohn, H. (2001) "Social security and demographic uncertainty: the risk-sharing properties of alternative policies," in J. Y. Campbell and M. Feldstein ed., Risk Aspects of Investment-based Social Security Reform, The University of Chicago Press, Chicago, pp.203-241.

Burbidge, J. B. (1983) "Social security and savings plans in overlapping-generations models," Journal of Public Economics, 21, pp.79-92.

Feldstein, M. (1974) "Social security, induced retirement and aggregate capital accumulation," Journal of Political Economy, 82, pp.905-926.

Genda, Y. (1997) "Chansu wa ichido: sedai to chingin kakusa" [One chance: Generations and wage differentials] (in Japanese) The Japanese Journal of Labour Studies, 449, pp.2-12.

Greenspan, A. (1999) "On investing the social security trust fund in equities," Testimony before the Subcommittee on Finance and Hazardous Materials, Committee on Commerce, U.S. House of Representatives, March 3.

Hatta, T. and Y. Oguchi (2001) Nenkin Kaikaku Ron [Social Security Reform] (in Japanese), Nihon Keizai Shinbusha, Tokyo.

Kato, R. (1998) "Transition to an aging Japan: Public pension, savings, and capital taxation," Journal of the Japanese and International Economies, 12, pp.204-231. 
Myles, D.G. (1995) Public Economics, Cambridge University Press, Cambridge.

Oshio, T. (2003) "Net pension liabilities, intergenerational equity, and pension reforms," Pie Discussion Paper, 131.

Sakaguchi, C. (2003) "On the outlook of the benefits and taxes in the 2004 Pension Reform: An abstract of Sakaguchi's Proposal," (in Japanese) a paper presented to the Economic and Fiscal Council, Cabinet Office, September 9.

Shoven, J. B. ed. (2000) Administrative Aspects of Investment-based Social Security Reform, The University of Chicago Press, Chicago.

Smetters, K. (2003) "Is the social security trust fund worth anything?" NBER Working Paper, 9845.

Smith, A. (1982) "Intergenerational transfers as social insurance," Journal of Public Economics, 19, pp.97-106.

Tamaki, N. (2003) "A study of the investment of Japan's public pension reserve fund-How should the government behave as an institutional investor?" NIRA Working Paper, 2003-2.

Uemura, T. (2001) "Kouteki nenkin no shukushou to kokko futan no keizai kousei bunseki" [Economic welfare analysis on downsizing social security and government subsidies to pension benefits] (in Japanese) JCER Economic Journal, 42, pp.205-227. 
Figure 1 The optimal combination of the tax rate and the trust fund

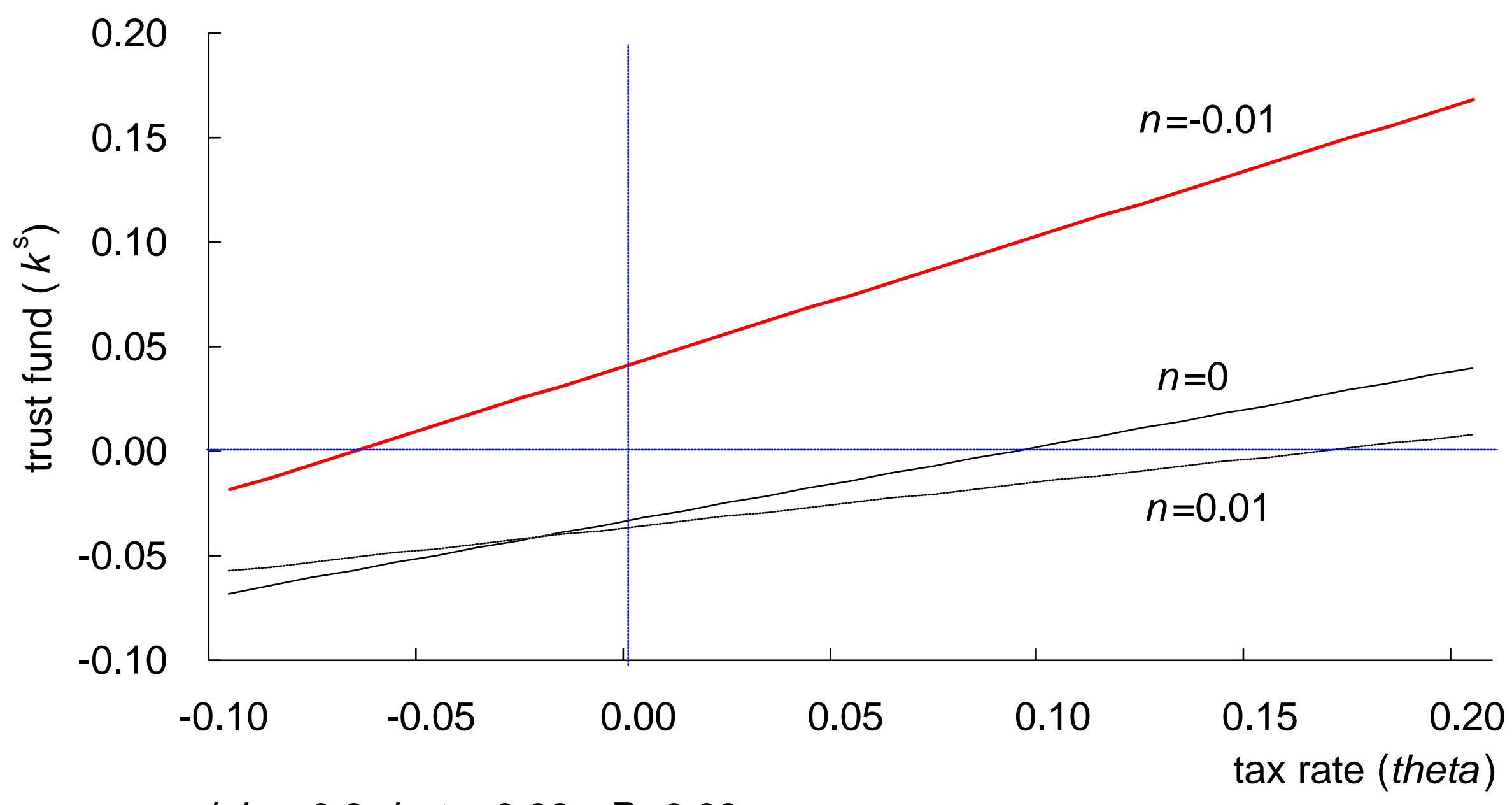


Figure 2 The optimal combination of the tax rate and the trust fund

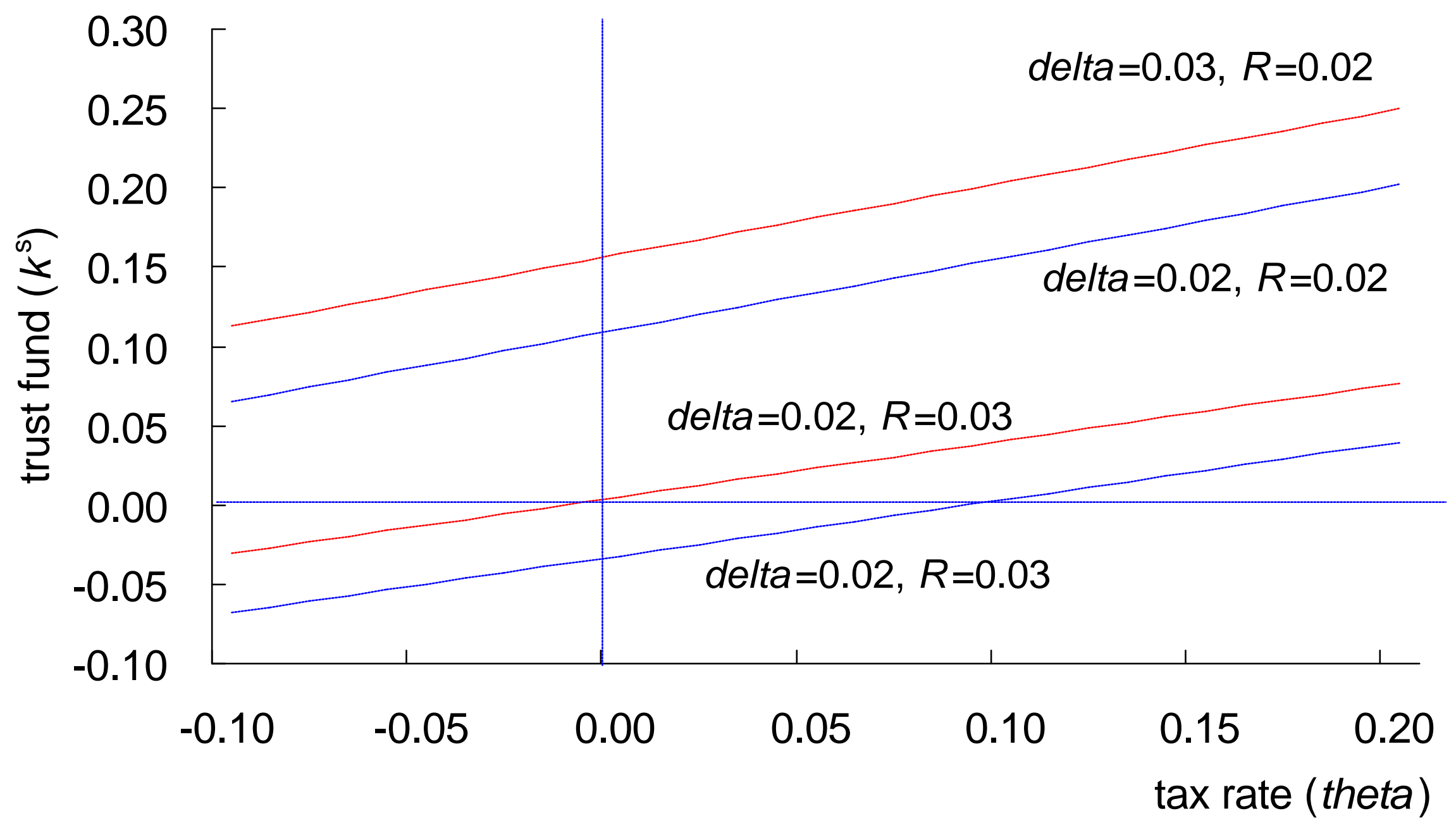


Table 1 Adjustment of the tax rate, benefit, and trust fund in response to a temporary demographic shock

\section{A small open economy}

\begin{tabular}{|c|c|c|c|c|c|c|c|c|}
\hline \multirow[t]{2}{*}{ period } & \multirow{2}{*}{$\begin{array}{r}\text { option } \mathrm{A} \\
\text { tax rate }(\%) \\
\end{array}$} & \multirow{2}{*}{$\begin{array}{r}\text { option B } \\
\text { tax rate(\%) }\end{array}$} & \multicolumn{2}{|c|}{ option C } & \multirow{2}{*}{$\begin{array}{r}\text { option } A^{\prime} \\
\text { benefit }\end{array}$} & \multirow{2}{*}{$\begin{array}{r}\text { option B' } \\
\text { benefit }\end{array}$} & \multicolumn{2}{|c|}{ option C' } \\
\hline & & & tax rate(\%) & trust fund & & & benefit & trust fund \\
\hline-2 & 8.9 & 10.0 & 10.0 & 0.00386 & 0.0320 & 0.0414 & 0.0414 & 0.00386 \\
\hline-1 & 8.9 & 10.0 & 10.0 & 0.00386 & 0.0320 & 0.0414 & 0.0414 & 0.00386 \\
\hline 0 & 8.9 & 10.0 & 10.0 & 0.00386 & 0.0320 & 0.0414 & 0.0414 & 0.00386 \\
\hline 1 & 12.1 & 13.8 & 10.0 & 0.00286 & 0.0237 & 0.0314 & 0.0414 & 0.00286 \\
\hline 2 & 8.9 & 10.0 & 11.5 & 0 & 0.0320 & 0.0414 & 0.0359 & 0 \\
\hline 3 & 8.9 & 10.0 & 11.5 & 0 & 0.0320 & 0.0414 & 0.0359 & 0 \\
\hline 4 & 8.9 & 10.0 & 11.5 & 0 & 0.0320 & 0.0414 & 0.0359 & 0 \\
\hline 5 & 8.9 & 10.0 & 11.5 & 0 & 0.0320 & 0.0414 & 0.0359 & 0 \\
\hline 6 & 8.9 & 10.0 & 11.5 & 0 & 0.0320 & 0.0414 & 0.0359 & 0 \\
\hline
\end{tabular}

\section{A closed economy}

\begin{tabular}{|c|c|c|c|c|c|c|c|c|}
\hline period & option A & option B & \multicolumn{2}{|c|}{ option C } & option $A^{\prime}$ & option B' & \multicolumn{2}{|c|}{ option C' } \\
\hline & tax rate $(\%)$ & tax rate $(\%)$ & tax rate $(\%)$ & trust fund & benefit & benefit & benefit & trust fund \\
\hline-2 & 8.9 & 10.0 & 10.0 & 0.00386 & 0.0320 & 0.0414 & 0.0414 & 0.00386 \\
\hline-1 & 8.9 & 10.0 & 10.0 & 0.00386 & 0.0320 & 0.0414 & 0.0414 & 0.00386 \\
\hline 0 & 8.9 & 10.0 & 10.0 & 0.00386 & 0.0320 & 0.0414 & 0.0414 & 0.00386 \\
\hline 1 & 11.1 & 12.7 & 9.2 & 0.00522 & 0.0260 & 0.0330 & 0.0414 & 0.00522 \\
\hline 2 & 8.7 & 10.1 & 11.3 & 0 & 0.0329 & 0.0420 & 0.0359 & 0 \\
\hline 3 & 8.9 & 10.0 & 11.6 & 0 & 0.0323 & 0.0416 & 0.0359 & 0 \\
\hline 4 & 8.9 & 10.0 & 11.8 & 0 & 0.0321 & 0.0414 & 0.0359 & 0 \\
\hline 5 & 8.9 & 10.0 & 11.8 & 0 & 0.0320 & 0.0414 & 0.0359 & 0 \\
\hline 6 & 8.9 & 10.0 & 11.8 & 0 & 0.0320 & 0.0414 & 0.0359 & 0 \\
\hline
\end{tabular}

(Note) It is assumed that the population growth rate falls to minus $1 \%$ in period 1 from $0 \%$ and returns to $0 \%$ in period 2 .

The reduction in the tax rate to $9.2 \%$ in period 1 in option $\mathrm{C}$ in a closed economy is due to an incease in wage. 
Figure 3a Policy impact in a small open economy (1)

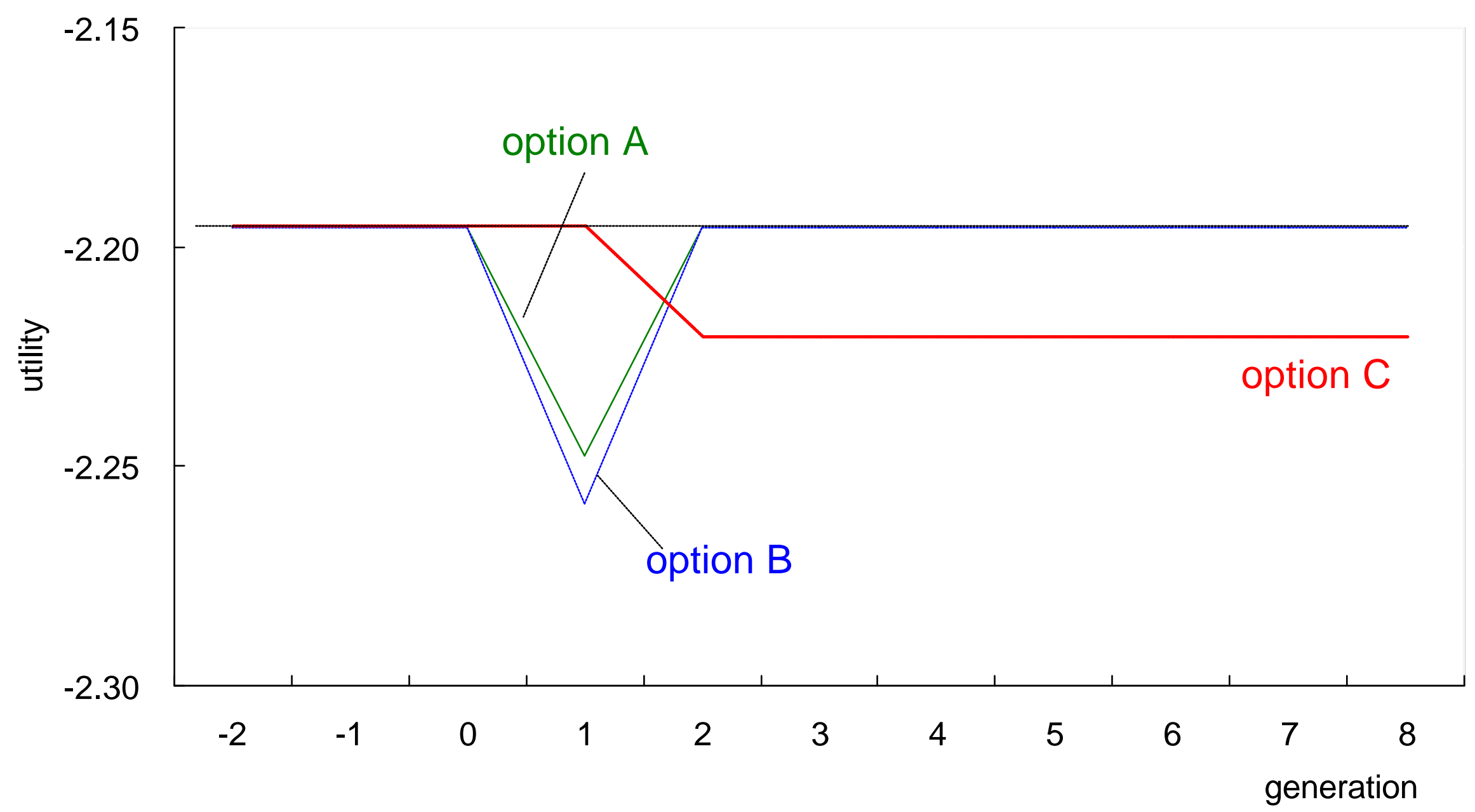


Figure $3 b$ Policy impact in a small open economy (2)

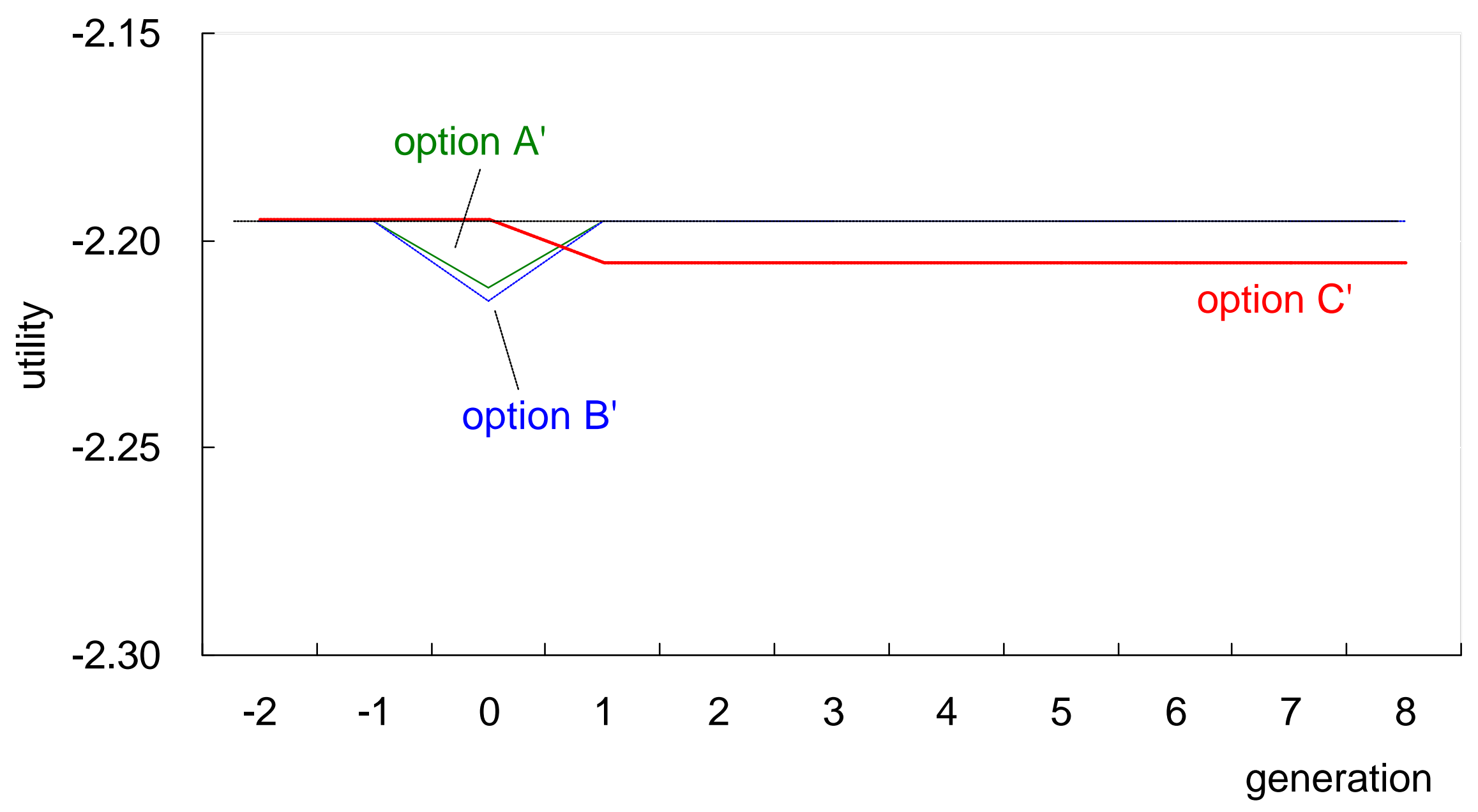


Figure 4a Policy impact in a closed economy (1)

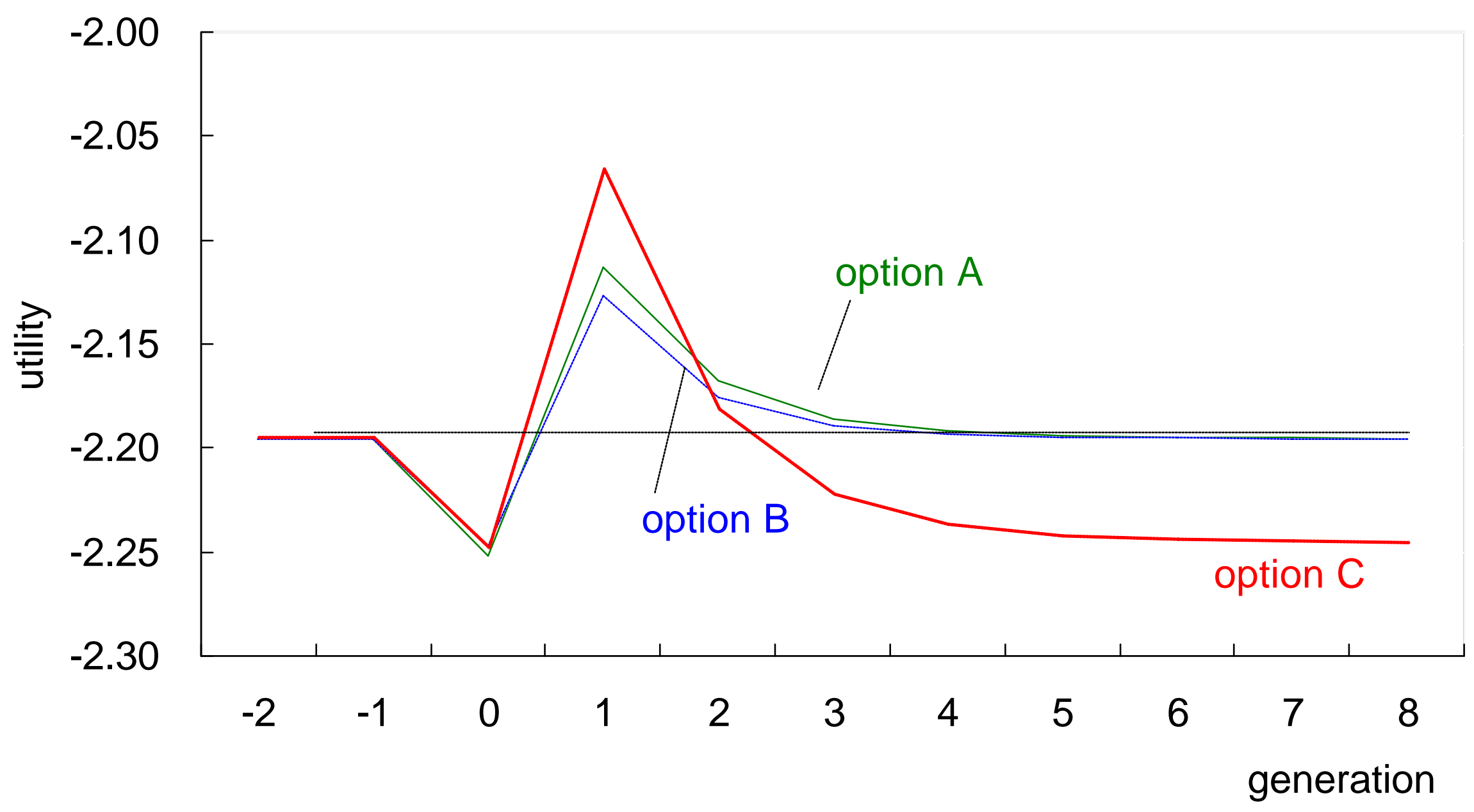


Figure 4b Policy impact in a closed economy (2)

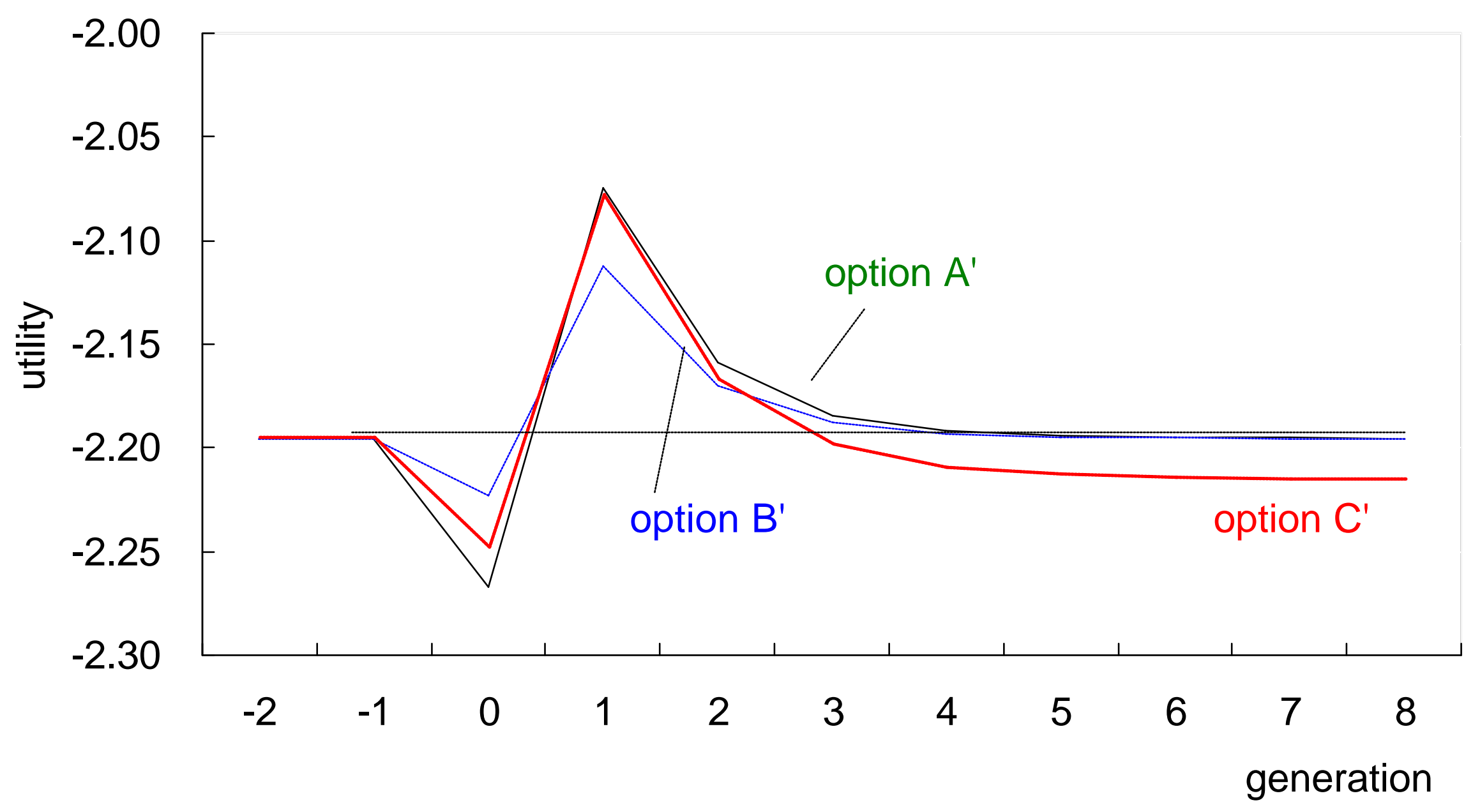

